\title{
Um Contraponto Fraco a um Modelo Forte: 0 Supremo Tribunal Federal, a última palavra e o diálogo
}

\author{
A Weak Counterpoint to a Strong Model: the Supreme Court, the last word \\ and the dialogue
}

\author{
Katya Kozicki \\ Pontifícia Universidade Católica do Paraná, Curitiba - PR, Brasil \\ Universidade Federal do Paraná, Curitiba - PR, Brasil
}

Eduardo Borges Araújo

Universidade de Brasília, Brasília - DF, Brasil

\begin{abstract}
Resumo: O presente artigo pretende analisar criticamente as características do modelo brasileiro de controle de constitucionalidade, discutindo o alegado protagonismo do Supremo Tribunal Federal e apostando no diálogo institucional entre os poderes na interpretação da constituição. Além da introdução e da conclusão, a estrutura deste trabalho é composta de três outros tópicos. Caberá ao primeiro resgatar o histórico da concentração de poderes, promovida pela Constituição Federal de 1988 e pelas legislações posteriores em torno da Corte, cuja atuação será criticada no segundo tópico. No terceiro, será trazida a proposta do diálogo e, por fim, serão traçadas as conclusões, atentando ao perverso efeito da ausência de diálogo entre Poderes Judiciário e Legislativo.
\end{abstract}

Palavras-chave: Supremo Tribunal Federal. Modelos de Controle de Constitucionalidade. Diálogo Institucional.

\begin{abstract}
The present article aims to critically analyze the characteristics of the Brazilian model of judicial review, questioning the alleged protagonism of the Supreme Court and proposing a institutional dialogue between Powers in the interpretation of the Constitution. Apart from the introduction and conclusion, its structure consists of three topics. First, it will be rescued the concentration of powers promoted by the Federal Constitution of 1988 and subsequent laws on the Court, whose performance will be criticized on the second topic. In the third, it will be discussed the proposition of the dialogue and, ultimately, conclusions will be drawn, noting the perverse effect of the absence of dialogue between the Judicial and Legislative branches.
\end{abstract}

Keywords: Supreme Federal Court. Models of Judicial Review. Institutional Dialogue.

Recebido em: 19/03/2015

Revisado em: 24/07/2015

Aprovado em: 11/08/2015 


\section{Introdução}

A Constituição dos Estados Unidos não dispõe expressamente sobre o controle judicial de constitucionalidade de lei. A competência do Poder Judiciário para anular atos normativos do Poder Legislativo seria extraída da história, da estrutura e da disposição da constituição por John Marshall, em 1803, ao julgar o caso Marbury v. Madison. A importância da decisão está mais nos argumentos ventilados pelo Justice para afirmar a competência da Corte no exercício da revisão judicial do que no resultado desse julgamento (SILVA, 2009, p. 137). Em sua análise sobre a lógica desenvolvida por Marshall, Carlos Santiago Nino (1996, p. 196) entenderia que a decisão confunde problema prático com problema lógico. A leitura da constituição como lei superior, inalterável por meios ordinários, não implica dizer qual órgão soberano responsável por sua aplicação e fiscalização. Logo, chegaria John Marshall à conclusão equivocada de que a ausência de controle judicial de constitucionalidade na ordem jurídica, além de logicamente impossível, negaria a supremacia da Constituição. A supremacia da Constituição, nos termos de Marbury v. Madison, conduziria à supremacia do Poder Judiciário.

Ainda que alternativas fossem possíveis ao desenho institucional americano, a tradição afirmou e a prática encarnou a revisão judicial (DWORKIN, 1996, p. 7). Um modelo similar de controle de constitucionalidade seria instituído pelo Brasil com a Constituição de 1891. Em 1920, a Constituição da Áustria proporia a alternativa ao modelo estadunidense com a criação da jurisdição concentrada. Ao final da Segunda Guerra, a Europa experimentaria um processo de reconstitucionalização: a Alemanha promulga a Lei Fundamental de Bonn, no ano de 1949, cuja guarda competia à Corte Constitucional, e a Itália, ainda que a sua Constituição de 1947 previsse uma Corte Constitucional, a institui de vez em 1965. Em seguida, a dita terceira onda de democratização (HUNTIGTON, 1991, p. 26) trouxe novas constituições para Portugal, em 1976, Espanha, em 1978, e Brasil, em 1988.

Entre todas elas, a Constituição de 1988 "[...] foi a que mais depositou confiança no papel do direito e do Judiciário" (MENDES, 2008, p. 18). O presente artigo tem por objetivo desenhar criticamente as princi- 
pais características do modelo brasileiro de judicial review, que garante ao Supremo Tribunal Federal a competência para exercer tanto o controle concentrado quanto o controle difuso de constitucionalidade, sem atribuir à Corte a tão suscitada "última palavra" em controvérsias constitucionais - simplesmente porque não há última palavra. Para discutir a proeminência do Supremo Tribunal Federal e apostar no diálogo entre os Poderes na exegese do texto constitucional, optou-se por reconstruir o histórico das competências da Corte, desde sua criação pela Constituição de 1891, com a instituição do modelo difuso de controle, até sua assunção ao posto de "guarda da constituição" pela Constituição de 1988, com a consolidação do modelo concentrado de controle. Cumprido o resgate histórico, passa-se a discutir a efetiva atuação do Supremo Tribunal Federal, cuja discurso termina por esconder um Tribunal pouco disposto a enfrentar o legislador em causas de maior potencial sociopolítico. Por último, após a análise dos perversos efeitos do discurso da "última palavra" sobre o modelo brasileiro, será trazida a proposta do diálogo institucional a partir das formas fracas de judicial review, que se preocupam em atribuir a todos os Poderes igual prerrogativa de interpretação da constituição.

\section{2 "Tijolo por Tijolo" em uma Corte (quase) Mágica: a constru- ção do modelo brasileiro de controle de constitucionalidade}

O modelo brasileiro de controle de constitucionalidade seria instituído na Constituição da República de $1891^{1}$. Definiria a primeira Carta republicana as competências do Supremo Tribunal Federal, criado sob a inspiração da Supreme Court of the United States, para processar e julgar "todas as causas propostas contra o Governo da União ou Fazenda Nacional, fundadas em disposição da Constituição" e "quando se contestar a validade de leis ou de atos do governo dos Governos do Estado em face da Constituição". Assim nasceria um modelo difuso e posterior de controle das leis semelhante ao controle exercido pelas cortes estadunidenses.

\footnotetext{
1 Antes disso, vale lembrar-se do Decreto n. 848 de 1890, que já autorizava o Supremo Tribunal Federal a julgar, em grau de recurso e em última instância, questões de constitucionalidade.
} 
A influência norte-americana far-se-ia presente também no princípio da separação dos poderes. A Constituição de 1891, em seu artigo 15, determinava que o Executivo, o Legislativo e o Judiciário eram harmônicos e independentes entre si. Adotando uma linha de autocontenção, a Corte hesitaria em exercer a revisão judicial e, assim, pretenderia não interferir sobre as ações dos demais poderes. A autocontenção judicial, contrária ao ativismo judicial, revelar-se-ia em três ações, reiteradamente adotadas - pelo menos até 1988. Primeiro, o Supremo não aplicaria diretamente as normas constitucionais às situações não previstas expressamente em sua esfera de incidência. Segundo, quando declarava a inconstitucionalidade de leis e atos normativos, valer-se-ia de critérios hermenêuticos rígidos e conservadores. Por fim, omitia-se da discussão sobre políticas públicas (BARROSO, 2010, p. 9). Decisões em matéria constitucional seriam recebidas como indevida intervenção do direito em áreas exclusivas da política, consagrando a separação dos poderes como uma distribuição estanque de funções (SILVA, 2009, p. 215).

Nesse momento histórico, destacar-se-ia o papel exercido por dois juristas no processo de consolidação e afirmação do controle de constitucionalidade. Ministro do Supremo entre os anos de 1907 e 1921, Pedro Lessa seria vinculado à doutrina do habeas corpus (HORBACH, 2007, p. 76). O desenvolvimento e consolidação desse instituto buscaria ampliar as garantias fundamentais dos cidadãos, sobretudo frente a atos do Poder Público. Ao lado a Pedro Lessa, Rui Barbosa também seria relacionado à doutrina, cujo marco inicial remeteria aos pedidos de habeas corpus por ele impetrados quando da decretação de estado de sítio no ano de 1892 por Floriano Peixoto. Rui Barbosa convenceria o Tribunal da possibilidade de aferir da legalidade de atos do Poder Executivo por meio de habeas corpus. O Supremo, logo, passaria a interpretar ampliativamente a liberdade de locomoção, bem jurídico imediatamente tutelado pelo habeas corpus, estendendo sua esfera de proteção a direitos correlatos. A doutrina nacional do habeas corpus buscaria "[...] melhorar os costumes da República, que nunca se esmerou em respeitar na prática o idealismo dos fundadores e nunca se revelou exemplar no respeito aos princípios da Constituição [...]" (TRIGUEIRO, 1981, p. 52). 
O primeiro passo significativo em direção ao modelo concentrado e abstrato seria dado pela Constituição de 1934, cujo texto preveria mecanismos de intervenção da União sobre os Estados quando violados os princípios constitucionais sensíveis do seu artigo $7^{\circ}$, I, $a$ a $h,^{2}$. A “declaração de inconstitucionalidade para evitar a intervenção federal”, conferida unicamente ao Procurador-Geral da República, condicionava a eficácia de lei interventiva à declaração de sua constitucionalidade pelo Supremo Tribunal, que, de modo inédito, tornar-se-ia competente para aferir a constitucionalidade de lei em tese. Embora estivesse "vedado ao Poder Judiciário conhecer de questões exclusivamente políticas", a representação seria uma fórmula judicial de resolução de conflito que deslocaria a questão do político ao jurídico (MENDES, 1990, p. 22).

Com a Emenda Constitucional n. 16 de 1965 seria inserida na Constituição Federal de 1946 a representação de inconstitucionalidade. Confiada exclusivamente ao Procurador-Geral da República, a representação seria meio apta a instar decisões do Supremo Tribunal Federal acerca da constitucionalidade de lei ou ato normativo, fosse federal ou estadual. O mérito da emenda, portanto, seria afirmar a tendência e implantar o controle abstrato. $\mathrm{O}$ alcance material da ação seria ampliado, tutelando não só princípios sensíveis como também direitos objetivos. Ao término, “[...] toda lei de nosso ordenamento jurídico [...] poderia ser objeto de um exame de constitucionalidade, mediante uma ação direta ou específica, destinada exclusivamente a liquidar o ponto controverso" (BONAVIDES, 2010, p. 330).

A Constituição de 1988, símbolo da redemocratização do País, alargou a titularidade e o escopo do direito de ação ao Supremo Tribunal Federal. O seu artigo 103 trouxe sete novos atores legitimados ao ajuizamento de ação direta de inconstitucionalidade - ação que sucedeu a representação. Também foram criados a ação direta de inconstituciona-

2 A Constituição de 1934 autorizava a intervenção da União sobre os Estados caso desrespeitados os seguintes princípios: i) forma republicana representativa; ii) independência e coordenação de poderes; iii) temporariedade das funções eletivas; iv) autonomia dos municípios; v) garantias do Poder Judiciário e do Ministério Público locais; vi) prestação de contas da Administração; vii) possibilidade de reforma constitucional e possibilidade do Poder Legislativo para decretá-la; e viii) representação das profissões. 
lidade por omissão e o mandado de injunção, ambos voltados para a resolução de condutas, omissivos do legislador que colocasse em risco a efetividade de normas constitucionais. Ao fim, instituiu-se, de modo subsidiário, a arguição de descumprimento de preceito fundamental, manejada para reparar ou evitar lesão resultante de ato do Poder Público.

Em 1993, a promulgação da Emenda Constitucional n. 3 instituiu a ação declaratória de constitucionalidade, cujo papel no modelo brasileiro de controle seria provocar o Supremo Tribunal Federal a decidir controvérsia ou dúvida sobre natureza constitucional de uma norma capaz de gerar um estado de incerteza jurídica. Além disso, a Emenda regulamentou a eficácia ex-nunc de decisões do Supremo e o instrumento da ADPF. Após seis anos, o Congresso Nacional promulgou duas leis relevantes ao controle de constitucionalidade no Brasil: a Lei n. 9.868, que dispõe sobre o rito das ADI e ADC no Supremo Tribunal Federal, e a Lei n. 9.882, que estabelece o processo e julgamento de ADPF.

A última etapa do processo de concentração do modelo brasileiro tomou espaço no ano de 2004, com a aprovação da Emenda Constitucional n. 45. Formulou-se o instituto da Súmula Vinculante, cuja aprovação pelo Supremo seria - ao menos em teoria - condicionada a reiteradas decisões sobre matérias constitucionais. Uma vez aprovada, a súmula vincularia não só o Poder Judiciário, como também a Administração Pública direta e indireta, nos três níveis federativos. A aprovação, a revisão ou o cancelamento poderiam ser requeridos somente pelos agentes previstos no artigo 103 da Constituição de 1988. Quanto ao controle difuso, a Emenda n. 45 condicionou a admissibilidade de recurso extraordinário à presença de repercussão geral, com a Corte aferindo a relevância jurídica, política, social ou econômica da matéria discutida.

Para os mais desatentos, a concentração do modelo brasileiro conduziu a um modelo europeu, corriqueiro e superficialmente caracterizado como repressivo e concentrado. É nessa simplificação que reside o erro em pensar que "[...] com o aumento essa concentração também no Brasil, o Supremo Tribunal Federal estaria a um passo de se transformar em um tribunal constitucional por excelência" (SILVA, 2009, p. 216). Bastaria a análise das características do modelo europeu que, frequentemente eram 
ignorados, para evidenciar a distância entre um "tribunal constitucional por excelência" e o Supremo Tribunal Federal.

Ao final da Segunda Guerra Mundial, a Europa passou por uma reconstitucionalização que moldou as instituições. O modelo continental de jurisdição constitucional apresentou-se como fenômeno pós-autoritário, cujos magistrados não gozavam de mandatos vitalícios e cuja nomeação exigia maioria parlamentar e consenso político. O Tribunal detém a decisão final do controle abstrato de inconstitucionalidade - sendo esse o traço típico do sistema concentrado. Quando decide a controvérsia, assim o faz colegiadamente, prezando pelo consenso em torno de uma resposta única (SILVA, 2009, p. 216).

Três são as marcas do processo decisório do STF que mostram ser o modelo brasileiro o que é desde 1891, é: “[...] uma cópia - às vezes bem feita, às vezes mal feita - do modelo norte-americano" (SILVA, 2009, p. 217). O Supremo Tribunal Federal não decide como instituição, uma vez que seus julgamentos são determinados pelo resultado da soma do voto de cada um de seus Ministros, sendo irrelevante a fundamentação desenvolvida para que a Corte decida pela constitucionalidade ou inconstitucionalidade. Daqui, inferem-se duas carências: unidade institucional e decisões objetivas. Por último, os julgamentos não são palco de deliberação interna, com os Ministros levando votos prontos sobretudo a julgamentos de maior relevância.

Em 1993, ao decidir a ação direta de inconstitucionalidade n. 939, o Supremo Tribunal Federal entendeu que, caso uma Emenda à Constituição, manifestação típica do Constituinte derivado, violasse o projeto original e básico da Constituição, poderia a inconstitucionalidade ser declarada pela Corte no exercício de sua função precípua de guardar a Constituição. Para o Ministro Celso de Mello, “[...] ao Supremo Tribunal Federal incumbe a tarefa, magna e eminente, de velar para que essa realidade [direitos e liberdades constitucionais] não seja desfigurada" (BRASIL, 1993).

A prerrogativa atribuída ao Supremo Tribunal Federal (STF) é superlativa (VIEIRA, 2008, p. 447). Além de Corte Constitucional, o STF desempenha a função de foro judicial especializado, ao julgar criminal- 
mente os ocupantes dos altos postos da República, e de tribunal de recurso de última instância, ao ratificar ou retificar o controle difuso realizado por tribunais inferiores. Entretanto, a leitura da Constituição não autoriza a atribuição da competência ao Supremo de fiscalizar os atos do poder constituinte derivado. Seu artigo 102, I, a, fundamento do controle judicial de constitucionalidade, diz respeito à lei ou ao ato normativo. "Extrair desta expressão a competência para julgar a constitucionalidade de emendas constitucionais parece um razoável desvio daquilo que o constituinte originário lhe reservou" (MENDES, 2008, p. 146).

Um modelo forte de jurisdição constitucional confere às Cortes a função de analisar a compatibilidade entre legislação e Constituição (TUSHNET, 2011, p. 325). Caso conclua pela inconstitucionalidade do certo ato normativo, a Corte deverá negá-lo com efeitos legais. Porém, de quando em vez, surgirão desacordos razoáveis sobre o que seria constitucional e inconstitucional. Nessas situações, ao contrário do correntemente defendido, o constitucionalismo não exige a prevalência do entendimento do Tribunal frente ao entendimento do Parlamento. Portanto, até modelos fortes de controle dispõem de mecanismos de revisão hábeis a responder às decisões judiciais consideradas equivocadas - como o processo de emenda à Constituição. Se, como há pouco visto, o Supremo Tribunal Federal estaria autorizado a julgar atos do poder constituinte de reforma, é razoável taxar o modelo brasileiro como ultraforte (SILVA, 2009, p. 217218).

\section{O Supremo Tribunal Federal Hoje: entre a "retórica do Guar- dião entrincheirado e a prática do Guardião acanhado"}

A Constituição Federal de 1988 trouxe novas ações constitucionais, ampliou o escopo material da revisão judicial e legitimou novos sujeitos. Reflexo da novidade foi o crescente ativismo da Corte, sob o pretexto de ser a "última trincheira do cidadão". O ativismo judicial não pode, entretanto, ser confundido com a judicialização da política. O desenho institucional traçado pela Constituição de 1988 reserva ao Supremo Tribunal Federal a "última palavra" no circuito decisório formal, que compreen- 
deria os procedimentos de deliberação e de decisão previstos pela Constituição (MENDES, 2010, p. 217). Em razão dessa circunstância, a arena jurídica é palco de resolução de questões moral, social e politicamente relevantes, devido a uma transferência de poder ao Judiciário, hoje autorizado a decidir questões que estavam fora das suas competências. Inserida no processo mundial de adoção ou de revisão de constituições que adotam cartas de direito e revisão judicial (HIRSCHL, 2004, p. 1), a Constituição de 1988 promove transferências de poder das instituições representativas a órgãos judiciários.

$\mathrm{O}$ ativismo judicial vincula-se a uma postura que defenderia uma participação mais ampla e intensa do Poder Judiciário na concretização dos valores e objetivos constitucionais. Tal proatividade conduz interferência sobre espaços até então tradicionalmente ocupados pelo Executivo e Legislativo. Às vezes, culmina só na "mera ocupação de espaços vazios" (BARROSO, 2010, p. 9). Gilmar Mendes, entretanto, entende ser o ativismo judicial também consequência do desenho institucional contemporâneo, "[...] um dado inevitável do novo contexto institucional que experimentamos" (PRESTES, 2007, p. 20). Três seriam os traços da postura ativista (BARROSO, 2010, p. 9). Em primeiro lugar, na aplicação direta da Constituição a situações não contidas expressamente em seu texto, sem levar em consideração manifestações da legislatura. Em segundo lugar, na declaração de inconstitucionalidade de atos legislativos ainda se ausente patente e ostensiva violação da Constituição e, em terceiro e último lugar, na imposição de deveres de fazer ou não fazer ao Poder Público. $\mathrm{O}$ ativismo judicial revela aspectos positivos e negativos. Por um lado, o Poder Judiciário estava atendendo demandas do cidadão, cujo acesso à justiça parece mais efetivo do que o acesso ao parlamento. A face negativa do ativismo, curiosamente não dirigida ao Poder Judiciário, estava em desvelar as dificuldades vivenciadas pelo Poder Legislativo.

Exemplo de ativismo judicial foi fornecido pelo caso da infidelidade partidária, em que o Supremo inovaria juridicamente para reconhecer a titularidade do mandato parlamentar ao partido político. Argumentando pela violação ao direito fundamental da oposição política, ao princípio democrático e ao exercício legítimo do poder, o Supremo decidiu que a troca injustificada de legenda partidária implicaria perda do mandato pelo 
candidato eleito, em uma decisão do Judiciário que foi muito bem recebida pela sociedade, que “[...] apoiou o ativismo do STF como uma espécie de remédio contra a inércia do Legislativo, uma ocupação legítima de um espaço vazio" (MENDES, 2010, p. 228).

É possível vislumbrar duas diferentes posturas na atuação do Tribunal. A "retórica do guardião entrincheirado" surgiu quando Supremo reafirmou a condição de guardião último da Carta, sem o qual o político não seria submetido ao jurídico. Uma Constituição desprovida de revisão judicial não passaria de conjunto de normas sem um instrumento de efetivação. Ao Supremo Tribunal Federal, logo, cabe levar os direitos a sério e fazer valer a Constituição. Ao decidir-se pela inconstitucionalidade de lei ou emenda constitucional, o faz para forçar o legislador ordinário, movido somente por interesses políticos egoístas e imediatos, a obedecer ao legislador extraordinário que se manifesta nos momentos constitucionais.

A dita supremacia do Supremo Tribunal Federal, protegida pela "retórica do guardião entrincheirado", produz efeitos perversos no circuito decisório formal inscrito na Carta de 1988. Primeiro, ao supor Ministros isolados do contexto em que se desenvolve a controvérsia constitucional, sublima seu papel político. Essa é a pedra de toque das chamadas teorias do pré-comprometimento. Imunes à irracionalidade que toma conta da maioria no momento de comoção social, os juízes decidiram com maior propriedade por serem atores externos do espírito independente "essencial à performance devotada de dever tão difícil”" (HAMILTON; JAY; MADISON, 2011, p. 597). De espírito independente, o juiz não é contagiado pelo estado patológico de tomada de decisões que contamina a multidão.

Além, a retórica tem o condão de liberar Corte e Parlamento do ônus argumentativo. À primeira, resta a interpretação e aplicação exegética da norma constitucional, sem exigir maior fundamentação. Já os legisladores, diante do ativismo judicial, se sentem isentos de fundamentar suas posições em razões constitucionais e se prendem à estrita legalidade de seus atos. Se a lei ou a política pública incorressem em vício, haveria a aferição posterior pelo Judiciário. A infalibilidade de juízes é presumida e, com isso, a possibilidade e os reflexos do seu erro são subestimados. $\mathrm{Na}$ decisão sobre a fidelidade partidária, por exemplo, afirmou-se que a 
resposta do Tribunal seria a melhor, "[...] sem que se possa cogitar de que as questões teriam sido melhor decididas por instituições majoritárias" (BRASIL, 2005). Nesse sentido, “[...] a 'excepcional personalidade do jurista' criada por uma 'formação ética' atua como indício da existência de uma ordem de valores justa, qual seja: 'uma decisão justa só pode ser tomada por uma personalidade justa"" (MAUS, 2000, p. 128). Na fuga da diversidade social, em que foi questionada a objetividade dos valores sociais, seria comum a transferência do superego da sociedade ao Judiciário. Discussões e procedimentos indispensáveis à construção política das normas e nas concepções de valores são eliminados por meio da centralização da "consciência" social na Justiça.

A "prática do guardião acanhado", do outro lado, está na tímida atuação da Corte no julgamento de casos delicados, ainda que essenciais à proteção e à promoção de direitos. Por vezes, retomando uma conduta típica da autocontenção judicial, o Tribunal utiliza critérios hermenêuticos rígidos e conservadores, desperdiçando relevantes espaços interpretativos que permitem uma atuação mais interventiva. Essas decisões acanhadas são consequência da missão heroica de salvaguardar direitos e liberdades que o próprio Tribunal coloca sobre suas costas. Caso, por exemplo, analisados os votos dos Ministros do Supremo Tribunal Federal no julgamento da ADPF n. 153, verifica-se que os argumentos evocados para afirmar a recepção da Lei de Anistia pela nova ordem constitucional amparar-se-iam em conceitos e formulações ultrapassados pela teoria e filosofia do direito (SILVA, 2009). O voto do Ministro Eros Grau, relator da arguição, é esclarecedor ao frisar que ao Supremo Tribunal Federal não incumbe alterar legislação, não podendo legislar ao julgar demandas, de maneira que "[...] revisão de lei de anistia, se mudanças do tempo e da sociedade a impuserem haverá - ou não - de ser feita pelo Poder Legislativo, não pelo Poder Judiciário" (BRASIL, 2010).

Quando não julga acanhadamente, a Corte utiliza-se de ferramentas que postergam ou evitam a tomada de decisão, como a definição da pauta de julgamento pelo Presidente do Tribunal e voto-vista. Uma análise sobre o trâmite das ações diretas de inconstitucionalidade ilustraria o argumento sobre definição da pauta (DIMOULIS; LUNARDI, 2008). Desde 1988, mais de quatro mil ações desse tipo foram propostas. As nor- 
mas para o processamento de ADI encontram-se na Lei n. 9.868/99, no regimento interno do Supremo Tribunal Federal, cujos dispositivos indicam que inexiste limitação para a possibilidade de o relator escolher o tempo de apresentar seu relatório e voto, vez que sempre há "acúmulo de serviço" 3 . O prazo legal de 30 dias, assim, é reiteradamente extrapolado. Ainda, o regimento interno faculta ao Relator da ADI decidir por si quando ele está habilitado ao julgamento, sem qualquer limitação temporal ou qualquer respeito à ordem de processo. "Dito de outra maneira, o RISTF delega ao Relator a competência de determinar a pauta" (DIMOULIS; LUNARDI, 2008, p. 4.362).

A ADI n. 3.685, cujo objeto era aliança partidária, foi distribuída em nove de março de 2006. Catorze dias depois veio a decisão definitiva do Plenário. Por outro lado, as ADIs n. 73 e n. 94, respectivamente sobre um decreto paulista que trata de questões ambientais e sobre os dispositivos da constituição rondoniense que regulamentam a Procuradoria de Rondônia, foram ajuizadas em 1989. Passados mais de 23 anos, vigora na primeira suspensão cautelar dos dispositivos. Na segunda, o julgamento ocorreu no dia 20 de junho de 2012. Um terceiro grupo é representado pela ADI n. 179 e n. 185, ajuizadas em fevereiro de 1990, questionando leis estaduais de baixa relevância sociopolítica. Nesse grupo, ainda não houve um julgamento definitivo. O quarto e último grupo abrange a ADI n. 494, proposta em 29 de abril de 1991, e a ADI n. 1648, proposta em 7 de agosto de 1997. Os pedidos de vista, neste último conjunto, postergaram até hoje uma decisão definitiva de mérito.

A Resolução n. 278, de 2003, do Supremo Tribunal Federal regulamentou o artigo 134 do Regimento Interno. Caso o Ministro entenda não estar imediatamente habilitado a proferir seu voto no processo, ele poderá pedir vistas por até 30 dias. Porém, o prazo é reiteradamente descumprido, sob a justificação regimental de "acúmulo de serviço". Assim, o tempo médio entre o pedido de vista e a apresentação do voto chega

3 O RISTF dispõe, em seu artigo 21, X, caber ao Relator pedir dia para o julgamento dos feitos em que estiver habilitado a proferir voto. Além, conforme o artigo 111, caput e III, de ser estipulado o prazo de 30 dias, excepcionado caso houver acúmulo de serviço. Por fim, as ações diretas de inconstitucionalidade possuem prioridade de julgamento no Plenário do STF, como fixado pelo artigo 145, caput e VIII. 
a mais de dois anos (RIBEIRO, 2011, p. 26). Por mais que seja o objetivo do pedido de vistas garantir o tempo necessário na formação da convicção do magistrado sobre o caso, sua deturpação provoca reflexos negativos sobre a deliberação colegiada de duas maneiras. Primeiro, pela demora na apresentação do voto após o pedido de vistas. Em regra, uma sessão do Pleno do Supremo Tribunal Federal bastaria para deliberação e decisão do processo. No julgamento da ADI n. 1.864, a primeira sessão ocorreu em 12 de abril de 2004, sendo suspensa pelo pedido de vista do Ministro Joaquim Barbosa. O julgamento seria retomado apenas em 8 de agosto de 2007 e, nos votos dos Ministros, foram constantes os lapsos, vide as respectivas declarações dos Ministros Marco Aurélio e Joaquim Barbosa: "Já tinha formado convencimento a respeito e fatalmente não me lembrarei mais dos parâmetros, em si, da controvérsia, quando vier à balha o processo [...]" e "[...] o voto está preparado há mais de dois anos, já não lembrava de muita coisa" (BRASIL, 2007). O segundo reflexo está no voto apresentado: em geral, baseado em citação doutrinária e pouco atento aos argumentos dos demais Ministros.

As audiências públicas previstas pelo Regimento Interno do Supremo Tribunal Federal foram disciplinas pela Emenda Regimental n. 29, em 2009. A sua principal finalidade é ouvir sujeitos não relacionados diretamente com o processo, mas que tenham expertise e autoridade na matéria discutida, para auxiliar com o esclarecimento de controvérsias técnicas, científicas, administrativas, políticas, econômicas e jurídicas. Das cinco audiências públicas realizadas no total, três ocorreram antes da Emenda e possuíram como objeto células-tronco embrionárias, importação de pneus usados e antecipação terapêutica do parto de fetos anencefálicos. Poucos Ministros compareceram às audiências, de maneira geral. Após a Emenda n. 29, o número de audiências públicas disparou, embora o quórum permaneça baixo. Discutiu-se o Sistema Único de Saúde, as políticas de ação afirmativa, o uso do amianto na construção civil, a proibição da venda de bebidas alcóolicas nas proximidades de rodovias, o financiamento eleitoral e demais.

É interessante notar que, em nenhuma das audiências publicas posteriores à Emenda n. 29, o Ministro responsável reservou tempo para questionamentos (ARIEDE, 2009, p. 59). Não obstante, ao proferir seu 
voto no julgamento da ADI n. 3510, sobre pesquisas científicas com células-tronco, afirmou o Ministro Gilmar Mendes que as iniciativas do Supremo revelariam que a Tribunal "[...] pode, sim, ser uma Casa do povo, tal qual o parlamento" (BRASIL, 2008). Mas a pouca teorização sobre o papel e a organização das audiências, cujo procedimento é decidido pelo Relator, distorcem seu papel deliberativo para transformá-las em "[...] teatro autolegitimatório ou autocongratulatório, com especialistas de todos os tipos apresentando argumento, mas com pouca ou nenhuma deliberação" (MENDES, 2010, p. 253).

A combinação entre a prática e a retórica culmina em uma Corte que "late, mas não morde". A responsabilidade da última palavra em matéria constitucional levou o Tribunal ao acanhamento frente a oportunidades para decidir mais ativamente, apenas agindo desse modo em casos com baixo e controlado potencial político. Melhor seria uma Corte mais modesta na retórica, que se colocasse como participante do processo interinstitucional de significação da constituição, mas que não se acanhasse quando possuísse bons argumentos, do que uma corte verborrágica, que se intimida ao desafiar o legislador (MENDES, 2008, p. 215).

\section{Nem Corte, nem Parlamento: o diálogo entre Poderes}

Até 1982, o Canadá era constitucionalmente regido pelas leis britânicas, que poderiam sofrer modificações a partir da iniciativa do Parlamento do Reino Unido e do consentimento do governo do Canadá. Com a nacionalização da Constituição canadense, o processo de emendas tornou-se faculdade exclusiva das suas instituições. A patriação representa uma oportunidade para localizar a identidade cultural do país em torno da sua constituição e, assim, substituir a dicotomia inglês-francês pelo multiculturalismo.

A incorporação de uma Carta de Direitos que possa ser fiscalizada e implementada pelo Poder Judiciário encontra resistência por parte das províncias canadenses. Para tornar o Canada Act consenso e resguardar a proteção dos direitos fundamentais por ele previstos às Cortes, os Primeiros-Ministros das províncias negociaram a introdução de duas 
proposições em seu texto - ambas referentes ao exercício do controle judicial de constitucionalidade.

A primeira demanda seria a inclusão da cláusula de limitações gerais, cuja redação era em muito influenciada pela linguagem dos documentos internacionais de direitos humanos. A cláusula admitiria restrição aos direitos fundamentais desde que observados os "limites razoáveis prescritos em lei que possam ser justificáveis em uma sociedade livre e democrática". A outra exigência acrescentaria ao texto a cláusula do não obstante - verdadeira inovação de desenho constitucional (TUSHNET, 2011, p. 341). Ainda que interpretar e implementar a Constituição fosse dever do Poder Judiciário, sendo a autoridade última nesta matéria a Suprema Corte, não seria importado o canônico modelo estadunidense de revisão judicial. A preocupação com a dificuldade contramajoritária levou os constituintes canadenses a bolar um modelo peculiar, com mecanismos já antecipados por algumas constituições provinciais.

A notwithstanding clause representa a conciliação entre ambas as tradições do sistema político canadense: a tradição britânica da soberania parlamentar e a tradição norte-americana de supremacia constitucional e de judicialização dos direitos constitucionais (JOHANSEN; ROSEN, 2012). Em suma, a cláusula autorizaria os Poderes Legislativos federal e provincial a editarem leis que repercutam sobre direitos fundamentais constitucionais ${ }^{4}$. A operacionalização do não obstante ocorreria a partir de lei expressa, cujo objeto seja desentrincheirar, pelo prazo de até cinco anos, direitos atinentes ao propósito da lei. Embora o Parlamento pudesse reeditar a lei indefinidamente, o prazo se justificaria por garantir a ocorrência de eleição entre edição e reedição da legislação. Assim, ofereceria à sociedade a oportunidade de discutir a adequação da utilização da cláusula. Com o suscitação do não obstante, a soberania do parlamento

\footnotetext{
4 Poderão os legisladores "desentrincheirar" os seguintes direitos fundamentais: liberdade de expressão, liberdade de consciência, liberdade de associação, direito à vida, direito à liberdade e segurança, liberdade de prisões e detenções arbitrárias, entre outros. Porém, alguns direitos estão fora do alcance da cláusula, como os direitos democráticos, os direitos de mobilidade, os direitos de linguagem, os direitos da minoria à educação linguística e a igualdade entre gêneros.
} 
seria revivida por meio da competência revogadora de decisões judiciais de inconstitucionalidade.

Os sistemas de supremacia do Parlamento sofreriam profundos e, às vezes, debilitantes golpes no correr do século XX, cuja experiência institucional comprovaria a incapacidade dos limites puramente políticos em conter a caminhada da legislatura rumo a regimes totalitários ou autoritários. Após a Segunda Guerra Mundial, o modelo de revisão judicial disponível era apenas o modelo forte dos Estados Uni$\operatorname{dos}^{5}$, cujas três principais marcas foram reproduzidas com a expansão do constitucionalismo: direitos com status jurídico superior à de lei ordinária, o resguardo de direitos contra reformas legislativas e a proteção via jurisdição constitucional. Os favoráveis tanto à supremacia parlamentar e quanto ao constitucionalismo apontariam para a conflituosa relação presente nos modelos fortes entre a soberania do Povo e a soberania da Constituição. Por um lado, o direito ao autogoverno surge na legislação adotada indiretamente pelos representantes e diretamente pelos cidadãos e, em último caso, na própria Constituição. Do outro lado, haveria a competência das cortes constitucionais em negar efeito às legislações incompatíveis, no seu entender, com a Constituição (TUSHNET, 2011, p. 328).

Os constitutional designers enfrentariam tais dificuldades ao elaborar mecanismos que aliviassem a tensão, como a instituição de processos distintos para a escolha dos Ministros de tribunais constitucionais e a imposição de limites ao efeito preclusivo de declarações judiciais de inconstitucionalidade. Mesmo assim, pensar em controle de constitucionalidade implicaria fazê-lo a partir do modelo forte estadunidense. Por

\footnotetext{
5 A decisão em Marbury v. Madison consolidou a prerrogativa da Suprema Corte em declarar a inconstitucionalidade de atos normativos promulgados pelo Congresso ou pela Presidência. Entretanto, o escopo desse poder e sua relação com a interpretação realizada pelos outros Poderes sobre a Constituição permaneceriam em aberto. Seria estabelecido um sistema "departamentalista" de revisão judicial, em que cada Poder era competente para analisar a constitucionalidade de atos promovidos por outro Poder, desde que influenciassem na sua operação. Entre o final do século XIX e a metade do século XX, o departamentalismo desapareceria para abrir lugar à forma forte de revisão judicial, em que a responsabilidade pela interpretação da Constituição seria atribuída a uma única instituição - o Poder Judiciário (TUSHNET, 2003a, p. 2.783).
} 
muito tempo, esse modelo único forneceria um forte argumento contrário à atribuição de funções às Cortes na implementação de políticas públicas. A verdadeira inovação no desenho constitucional viria apenas com a Constituição do Canadá, cuja cláusula do não obstante inventaria - ou, para ser mais preciso, reinventaria - o modelo fraco de revisão judicial. De fato, a prática da revisão judicial fora pensada em termos fracos em Marbury v. Madison, porém, com o passar do tempo, as transformações no instituto levariam ao gradual "fortalecimento", de maneira que a forma fraca precisou ser reinventada ao final do século XX (TUSHNET, 2003a, p. 2.786).

Primeiro, a forma fraca de revisão judicial não deveria ser confundida com a restrição da amplitude do controle de constitucionalidade. No procedimentalismo de John Hart Ely, um exemplo somente, a Corte preocupar-se-ia em preservar a competição eleitoral e estimular as vias de expressão e canalização dos projetos coletivos. Como se órgão antitruste fosse (ELY, 1978, p. 488), atuaria na garantia da disputa política igualitária. No modelo fraco, o Tribunal seria apto a avaliar a adequação de toda legislação com todos os dispositivos constitucionais, mas a sua principal característica estaria em permitir à maioria legislativa ordinária a reversão das decisões judiciais em curto prazo. "A forma fraca de revisão responde à preocupação de que a forma forte de revisão autoriza que cortes com fraco pedigree democrático desbanquem as decisões tomadas por órgãos com pedigree democrático mais forte" (TUSHNET, 2003a, p. 2.786). Criar-se-ia um modelo de controle departamentalista distinto do criado em Marbury v. Madison, com cada Poder agindo conforme sua melhor interpretação.

Na contemporaneidade, são três diferentes tipos de modelos fracos de revisão judicial, muito embora a novidade dos modelos fracos torne possível e provável que as possibilidades institucionais estendam-se para além dos desenhos hoje em vigor (TUSHNET, 2011, p. 335). Dos três modelos, o mais "forte" torna as Cortes competentes para suspender os efeitos legais das legislações, fazendo com que o Parlamento responda à decisão judicial com legislação ordinária, ao invés do complexo processo 
de emenda constitucional. O Canadá é exemplo deste tipo de modelo ${ }^{6}$. No outro extremo, a versão mais fraca impõe um mandato interpretativo às Cortes. Uma diretiva legislativa condicionaria o Poder Judiciário a interpretar a legislação conforme a lista de direitos protegidos - protegidos, mas não entrincheirados. Seria uma Carta de Direitos promulgada com status de lei ordinária cujas disposições não estariam isentas à revogação ou alteração. São duas as ações possíveis da Corte neste modelo de revisão judicial. Em relação à lei vigente, a Carta deveria ser recebida como parâmetro hermenêutico a guiar a interpretação das leis. Quanto à legislação promulgada posteriormente, supõe-se que a legislatura desejaria respeitar os direitos por ela definidos na Carta. Logo, as futuras legislações deveriam ser lidas segundo o seu texto. Assim é o controle na Nova Zelândia - se é que consiste propriamente em controle judicial (TUSHNET, 2011, p. 331).

Em um patamar intermediário, as Cortes são incumbidas de declarar, em último caso, a incompatibilidade entre legislação e direitos fundamentais. Para tanto, deve-se entender por impossível a interpretação da legislação de forma que não sejam violados os direitos. Sendo a violação consequência indesejada das leis, camuflada sob os termos complexos, caberia ao Poder Judiciário aplicar o parâmetro interpretativo. $\mathrm{O}$ cenário mais provável, contudo, seria de uma redação precisa e clara, em que a violação de direitos configuraria real intenção do Legislativo - ou assim entenderia o Judiciário. De duas, uma: poderia o Legislativo almejar a violação ou entender que seu ato não contraria qualquer direito fundamental - entendimento contrário ao do Judiciário, o que apenas confirma-

\footnotetext{
6 A atual relevância da cláusula do não obstante é controvertida. Para Tushnet, trata-se de uma nonprovision cuja instrumentalização prévia a qualquer decisão judicial criou problemas. Os casos mais notáveis em que seu emprego ocorreu não parecem indicar que a cláusula foi utilizada para salvaguardar a legislação de conclusões judiciais equivocadas. Assim fez o Parlamento de Alberta, ao imunizar lei que definia o casamento como exclusivamente heterossexual (TUSHNET, 2003a). Peter Russel, embora reconheça que o histórico da cláusula não seja muito motivador, seu emprego constitucionalmente inteligente implica o respeito à democracia parlamentar para que o Judiciário não possua sempre a última palavra em questões de direitos e liberdades. A inclusão da cláusula representa a crença no contrapeso parlamentar às decisões judiciais equivocadas em questões fundamentais (RUSSEL, 1991).
} 
ria que "[...] o desacordo à flor da pele sobre justiça continua a ser a condição mais gritante da política" (WALDRON, 1999, p. 163). Em ambas situações, seria difícil imaginar uma resposta do Parlamento à declaração da Corte (TUSHNET, 2011, p. 333). Um modelo fraco intermediário seria instituído no Reino Unido, mediante promulgação do Human Rights Act de 1998. As reformas constitucionais propostas pelo Partido Trabalhista preocupar-se-iam em conferir plena eficácia aos direitos protegidos pela Convenção Europeia de Direitos Humanos, agora aplicáveis por cortes britânicas através de mandato interpretativo. Além, as Cortes superiores se tornariam competentes para declarar a incompatibilidade das leis ordinárias frente aos direitos protegidos pela Convenção Europeia, com o objetivo de o Parlamento responder à decisão por meio de uma lei compatível. "O Human Rights Act, então, busca introduzir um discurso de direitos no primeiro plano de uma cultura legal em que estava previa e largamente ausente" (GARDBAUM, 2001, p. 35). Mas o Poder Legislativo deveria tomar o cuidado em preservar sua soberania frente ao Poder Judiciário.

Em um mundo em que cortes e parlamentos discordariam razoavelmente sobre justiça e, especificamente, sobre a compatibilidade entre lei ordinária e lei suprema, o diálogo talvez seja a maior vantagem do modelo fraco de judicial review. O diálogo permitiria ao Judiciário informar o Legislativo sobre sua interpretação do texto constitucional e, também, autorizaria o Legislativo a responder e agir segundo sua interpretação, mas agora subsidiado pelo Judiciário sobre aspectos constitucionais das suas decisões que lhe faltassem em um primeiro momento. A forma fraca permitiria ao Legislativo a análise constitucional dos seus atos sem que lhe seja retirada a faculdade de reeditá-los caso conclua por sua inadequação ou inconsistência. "Neste sentido, um diálogo benéfico entre cortes e legislaturas substituiria o modelo americano de monólogo judicial" (GARDBAUM, 2001, p. 23).

A literatura constitucional dos países do Commonwealth, sobretudo no Reino Unido e na Nova Zelândia, seria fortemente influenciada pela doutrina canadense do diálogo, cujo início remeteria a 1997, com Peter Hogg e Allison Bushell (MENDES, 2010, p. 151). A análise dos casos em que o Tribunal reputou inconstitucionais atos do Parlamento chegaria à conclusão de que o legislador responderia ao julgador conscientemente 
com novas leis fundamentadas em termos constitucionais. Com isso, "[...] quando as leis tocam os limites da Carta e, em particular, quando novas leis são promulgadas para substituir aquelas já invalidadas em razão da própria Carta [...]" (HOGG; BUSHELL, 1997, p. 101), seu preâmbulo traria consigo explicações sobre os objetivos urgentes e as limitações razoáveis embutidas na legislação promulgada.

No contexto do diálogo, em que a decisão judicial suscitaria uma resposta consciente da legislatura, o controle de constitucionalidade não é exercido na condição de um veto. Para melhor ilustrar a ideia do diálogo, adaptá-la ao contexto brasileiro levaria à negação de que o Supremo Tribunal Federal detém a última palavra sobre o significado do texto constitucional. A declaração de inconstitucionalidade iniciaria uma comunicação interinstitucional, vez que o Parlamento deveria lidar com os argumentos trazidos pela Corte e conciliar objetivos sociais e direitos individuais. Melhor seria falar em última palavra provisória da rodada procedimental, em que Corte e Congresso possuiriam a legitimidade para serem ativistas desde que engajados no diálogo e no convencimento. A derrubada da última palavra alheia daria reinício ao circuito decisório com ônus argumentativo ao Poder cuja decisão foi substituída.

Judiciário e Legislativo possuiriam expertises distintas, cada qual analisando a mesma questão por um viés particular. Para instituir um diálogo democrático e evitar o monólogo da supremacia parlamentar ou judicial, indispensável que ambos se mantenham comedidos sobre a superioridade do respectivo julgamento e respeitosos frente à interpretação alheia. Ao final, "[...] melhores respostas são mais plausíveis de surgir quando produtos de julgamentos arrazoados e cautelosos da justificação de ações do Estado sob a luz dos valores políticos fundamentais normativos" (HIEBERT, 2004, p. 72). Trata-se de condição indispensável à construção de um constitucionalismo efetivamente democrático, em que o exercício do judicial review deixe de ser visto como uma atividade contramajoritária, desempenhada por sujeitos independentes do contexto social em que inseridos, mas sim como uma atividade afinada às exigências sociais, captando as aspirações populares e jurídicas em torno do texto constitucional e promovendo a comunicação e deliberação entre cidadãos e governantes (SIEGEL, 2006, p. 1.325) 


\section{Conclusão}

Localizar no Supremo Tribunal Federal a última etapa do circuito decisório delineado pela Constituição Federal de 1988, resultado de um processo de concentração das funções de controle de constitucionalidade em torno do Poder Judiciário, desvia a análise dos méritos das decisões para os mecanismos decisórios empregados pelo Tribunal. Verificou-se, nas práticas da Corte, um déficit deliberativo em nível interno, quanto à deliberação entre os Ministros, e em nível externo, quanto à deliberação entre o Supremo Tribunal Federal e demais instâncias democráticas de deliberação, sobretudo o Poder Legislativo. Em seguida, foram apresentados os modelos fracos de controle de constitucionalidade presentes nos países da Commonwealth, cuja particularidade está em possibilitar maior participação do Poder Legislativo no processo de interpretação constitucional e fomentar um diálogo entre Poderes.

A posição institucional, ocupada pelo Supremo Tribunal Federal, não abre ao Congresso Nacional maior espaço para interpretar a Constituição e decidir com autonomia. O tão alegado monopólio da Corte isenta o Parlamento de sua responsabilidade constitucional na elaboração de políticas públicas. Os reflexos negativos do modelo forte de controle já seriam antecipados na virada do século XX por James Bradley Thayer, para quem a proeminência dos Tribunais sobre os Parlamentos terminaria esvaziando a arena legislativa de questões de justiça e direito, relegando aos legisladores tão somente questões de legalidade e "[...] até mesmo nas questões de legalidade, eles sentiriam pouca responsabilidade; caso estejamos equivocados, eles dizem, as Cortes irão corrigir" (THAYER, 1893, p. 155-156).

\section{Referências}

\section{ARIEDE, Elouise Bueno. Audiências públicas no Supremo Tribunal}

Federal: um estudo comparativo de sua prática, antes e após o advento da Emenda Regimental n. 29 de 2009. 2011. 80 p. Monografia (Direito) Escola de Formação da SBDP, São Paulo, 2011. 
BARROSO, Luís Roberto. Constituição, democracia e supremacia judicial: direito e política no Brasil contemporâneo. Revista Jurídica da Presidência, Brasília, DF, v. 12, p. 3-41, fev.-maio, 2010.

BONAVIDES, Paulo. Curso de Direito Constitucional. 25. ed. atual. São Paulo: Malheiros Editores, 2010.

BRASIL. Supremo Tribunal Federal. Ação direta de inconstitucionalidade n. 939. 1993. Disponível em: < http://bit. ly/1JCmZJ9>. Acesso em: 28 ago. 2015.

BRASIL. Supremo Tribunal Federal. Ação direta de inconstitucionalidade n. 3.510. 2007. Disponível em: $<$ http://bit. ly/1LARNJD>. Acesso em: 28 ago. 2015.

BRASIL. Supremo Tribunal Federal. Ação direta de inconstitucionalidade n. 1.864. 2008. Disponível em: < http://bit. ly/1NEOUuA >. Acesso em: 28 ago. 2015.

BRASIL. Supremo Tribunal Federal. Arguição de descumprimento de preceito fundamental n. 153. 2005. Disponível em: < http://bit. ly/1hK2zUj>. Acesso em: 28 ago. 2015.

DIMOULIS, Dimitri; LUNARDI, Soraya Regina Gasparetto. Definição da pauta no Supremo Tribunal Federal e (auto)criação do processo objetivo. XVII CONGRESSO NACIONAL DO CONPEDI. Brasília, DF, 20, 21 e 22 de novembro de 2008. Anais... Brasília, DF, 2008. p. 4.3574.377 .

DWORKIN, Ronald. Freedom's Law: a moral reading of the American Constitution. Cambridge, MA: Harvard University Press, 1996.

ELY, John Hart Toward a Representation-Reinforcing Mode of Judicial Review. Maryland Law Review, [S.1.], v. 37, n. 3, p. 451-487, 1978.

GARDBAUM, Stephen. The New Commonwealth Model of Constitutionalism. American Journal of Comparative Law, [S.1.], v. 49, n. 4, p. 707-760, fall, 2001.

HAMILTON, Alexander; JAY, John; MADISON, James. The Federalist Papers. Raleigh, NC: Sweetwater Press, 2011. 
HIEBERT, Janet. Charter Conflicts: what is Parliament's role? Québec: McGill-Queens University Press, 2004.

HIRSCHL, Ran. Towards juristocracy: the origins and consequences of the new constitutionalism. Cambridge, MA: Harvard University Press, 2004.

HOGG, Peter W.; BUSHELL, Allison A. Courts And Legislatures - Or Perhaps The Charter of Rights Isn't Such A Bad Things. Osgoode Hall Law Journal, [S.1.], v. 35, n. 1, p. 75-124, spring 1997.

HORBACH, Carlos Bastide. Memória Jurisprudencial: Ministro Pedro Lessa. Brasília, DF: Supremo Tribunal Federal, 2007.

HUNTINGTON, Samuel. The third wave: democratization in the late Twentieth Century. Oklahoma: University of Oklahoma Press, 1991.

KELSEN, Hans. Jurisdição Constitucional. São Paulo: Martins Fontes, 2007.

KLAFKE, Guilherme Forma. Vícios no processo decisório do Supremo Tribunal Federal. 2010. 173 p. Monografia (Direito) - Escola de Formação da SBDP, São Paulo, 2010.

JOHANSEN, David; ROSEN, Philip. The notwithstanding clause of the Charter. Ottawa: Parliamentary Information and Research Service, 2012.

MAUS, Ingeborg. O judiciário como superego da sociedade - o papel da atividade jurisprudencial na "sociedade órfã". Novos Estudos, São Paulo, CEBRAP, n. 58, p. 183-202, 2000.

MENDES, Conrado Hübner. Controle de constitucionalidade e democracia. Rio de Janeiro: Elsevier, 2008.

MENDES, Conrado Hübner. Direitos fundamentais, separação de poderes e deliberação. São Paulo: Saraiva, 2010.

MENDES, Gilmar. Controle de Constitucionalidade: aspectos jurídicos e políticos. São Paulo: Saraiva, 1990.

NINO, Carlos Santiago. The constitution of deliberative democracy. New Haven and London: Yale University Press, 1996. 
PRESTES, Cristine. Uma revolução silenciosa no Supremo. Valor Econômico, São Paulo, v. 18, Caderno Especial, p. 20, out. 2010.

RIBEIRO, Caio Gentil. Voto-vista e deliberação no Supremo Tribunal Federal. 2011. 133 p. Monografia (Direito) - Escola de Formação da SBDP, São Paulo, 2011.

RUSSEL, Peter. Standing Up for Notwithstanding. Alberta Law Review, [S.1.], v. 29, p. 293-309, 1991.

SIEGEL, Reva. Constitutional Culture, Social Movement and Constitutional Change: the case of ERA. California Law Review, [S.1.], v. 94, p. 1.323-1.419, 2006.

SILVA, Virgílio Afonso da. O STF e o controle de constitucionalidade: deliberação, diálogo e razão. Revista de Direito Administrativo, São Paulo, n. 250, p. 197-227, 2009.

THAYER, James Bradley. The origin and scope of american doctrine of constitutional law. Harvard Law Review, [S.1.], v. 7, n. 3, p. 129-156, oct. 1893 .

TRIGUEIRO, Oswaldo. O Supremo Tribunal Federal no Império e na República. Arquivos do Ministério da Justiça, [S.1.], n. 157, ano 38, p. 40-57, jan.-mar. 1981.

TUSHNET, Mark. Alternative Forms of Judicial Review. Michigan Law Review, [S.1.], v. 101, n. 8, p. 2.781-2.802, aug. 2003a.

TUSHNET, Mark. New Forms of Judicial Review and the Persistence of Rights-and Democracy-Based Worries. Wake Forest Law Review, [S.1.], v. 38, p. 813-838, 2003 b.

TUSHNET, Mark. The Rise of Weak-Form of Judicial Review. In: GINSBURG, Tom; DIXON, Rosalind (Ed.). Comparative Constitutional Law. Cheltenham and Northampton: Edward Elgar, 2011. p. 321-333.

VIEIRA, Oscar Vilhena. Supremocracia. Revista Direito GV, São Paulo, v. 4, n. 2, p. 441-463, jul.-dez. 2008. 
WALDRON, Jeremy. Law and disagreement. Oxford: Oxford University Press, 1999.

Katya Kozicki é professora titular da PUC/PR e professora Associada da UFPR. mestre e doutora em Direito pela UFSC. Visiting Researcher Associate do Centre for the Studies of Democracy, University of Westminster (1998/19). Pesquisadora do Grupo de Pesquisa "Constitucionalismo e Democracia: filosofia e dogmática constitucional contemporâneas". Bolsista de Produtividade em Pesquisa do Conselho Nacional de Pesquisa. Visiting Research Scholar na Benjamin N. Cardozo School (2012-2013).

E-mail:kkozicki@uol.com.br.

Endereço Profissional: Rua Rubens Santos Costa, n. 32, Apto. 1202. Cristo Rei, Curitiba/PR. CEP: 80050-500.

Eduardo Borges Araújo é mestre em Direito pela UnB e Bacharel em Direito pela UFPR. Pesquisador do Grupo de Pesquisa "Constitucionalismo e Democracia: filosofia e dogmática constitucional contemporâneas". Advogado.

E-mail: eduardo.bfr@me.com.

Endereço: SQN 109, Bloco H, Apto. 606, Asa Norte, Brasília/DF. CEP: 70752-080. 
